$\mathrm{DE}$

M E D I C I N A

T R O P I C A L

$\mathrm{DE}$



JOURNAL OF THE SÃO PAULO INSTITUTE OF TROPICAL MEDICINE

1Universidade Federal do Ceará, Faculdade de Medicina, Departamento de Medicina Interna, Programa de Pós-Graduação em Ciências Médicas, Fortaleza, Ceará, Brazil

${ }^{2}$ Universidade de Fortaleza, Fortaleza, Ceará, Brazil

Correspondence to: Sandra Mara Brasileiro Mota

Universidade Federal do Ceará, Faculdade de Medicina, Departamento de Medicina Interna, Programa de Pós-Graduação em Ciências Médicas, Rua Costa Mendes, 1608, CEP 60020-181, Fortaleza, CE, Brazil

Tel: +55 8533668208

E-mail: sandramarabrasileiro@gmail.com

Received: 21 May 2020

Accepted: 4 July 2020

\section{Thrombotic microangiopathy due to Bothrops erythromelas: a case report in Northeast Brazil}

\author{
Sandra Mara Brasileiro Mota ${ }^{1}$, Polianna Lemos Moura Moreira \\ Albuquerque $^{\circledR 2}$, Geraldo Bezerra da Silva Júnior ${ }^{(i)}$, Elizabeth De Francesco \\ Daher ${ }^{(1)}$
}

\section{ABSTRACT}

Bothrops erythromelas are serpents that belong to the Viperidae family, which are the main species responsible for human snakebites in Ceara State, Northeast Brazil. Thrombotic microangiopathy (TMA) is an uncommon group of disorders characterized by microangiopathic hemolytic anemia (MAHA), thrombocytopenia and acute kidney injury (AKI), and occurrence after snakebites have been rarely reported. In this report, we described the case of a 57 year-old-man without comorbidities who was bitten by a Bothrops erythromelas on his right ankle. He presented with pain, edema and local bleeding. Symptomatology and laboratory tests were compatible with the diagnosis of TMA. He received specific antivenom and fluids replacement without any anaphylactic reaction. The conservative treatment was effective and there was no need for red blood cells transfusion or plasmapheresis. The aim of this report was to describe the first case of thrombotic microangiopathy following Bothrops erythromelas envenoming in the Northeast Brazil, providing insights about important mechanistic pathways of Bothrops snakebite-associated TMA and how to change the prognosis of the disease.

KEYWORDS: Thrombotic microangiopathy. Snakebite. Bothrops erythromelas. Acute kidney injury.

\section{INTRODUCTION}

Snakebite-related Thrombotic Microangiopathy (TMA) is characterized by thrombocytopenia, microangiopathic hemolytic anemia and acute kidney injury (AKI) ${ }^{1}$. Studies described TMA due to Viperidae bites by Daboia russelli (Russell's vipers) in India and in Sri Lanka, Cerastes cerastes in Europe, Proatheris superciliares in the United States of America, Bothrops lanceolatus in Martinique $^{2}$, and only three cases following Bothrops jararaca envenomation in Southeastern Brazil ${ }^{2,3}$. AKI associated with TMA has not been described in Bothrops envenomation in Northeast Brazil.

Thrombotic microangiopathy is associated with significant morbidity and mortality ${ }^{4}$. The knowledge on the prevalence of TMA in Bothrops envenomation, as well as the early diagnosis of this syndrome is essential for the prompt initiation of supportive and specific management to decrease adverse outcomes such as AKI, chronic kidney disease, hemorrhage and death ${ }^{5,6}$.

The aim of this study was to report the first case of thrombotic microangiopathy and AKI following Bothrops erythromelas snakebite envenomation (Viperidae family) in the Northeast of Brazil, highlighting current studies under a perspective 
of clinical applications. Although other snakebites are associated with the development of TMA, this pathophysiology remains poorly understood.

\section{CASE REPORT}

A 57-year-old man without previous comorbidities was bitten by a Bothrops erythromelas on his right ankle. He killed the snake and applied a tourniquet above the snakebite and attempted to extract the venom, a popular traditional treatment of snakebites in the locality where he lives. He was transferred to the Poison Control Center in the Instituto Doutor Jose Frota, a tertiary hospital in Fortaleza city, Ceara State, Northeast of Brazil. He was admitted $5 \mathrm{~h}$ after the snakebite and brought the snake, permitting its identification (Figure 1). On admission the patient presented with local pain, swelling and bleeding at the punctured site. Blood was collected and the laboratory findings were analyzed periodically (Table 1).

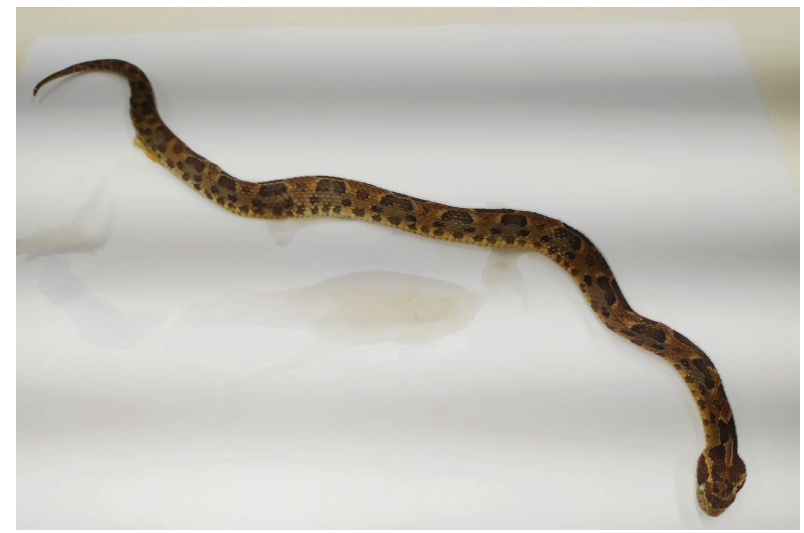

Figure 1 - Bothrops erythromelas (source: provided by the Poison Control Center in the Instituto Dr. Jose Frota, Ceara. The photograph is from the collection of the institution)

Laboratory features upon admission revealed a very prolonged prothrombin time (PT) and activated partial thromboplastin time (aPTT), i.e., blood was uncoagulable, the platelets count wad normal and serum creatinine was slightly elevated $(1.6 \mathrm{mg} / \mathrm{dL} ; \mathrm{RV}<1.3 \mathrm{mg} / \mathrm{dL})$. Four vials of specific antivenom (Anti Bothropic Serum - a polyvalent serum of equine origin, $\mathrm{F}(\mathrm{ab})_{2}$, against Bothrops species, $10 \mathrm{~mL} / \mathrm{vial}$, manufactured by Instituto Butantan, Sao Paulo, Brazil) were administered without any anaphylactic reaction. However, the patient evolved with increasing serum creatinine $(\mathrm{sCr})$ levels $(2.9 \mathrm{mg} / \mathrm{dL}$; $\mathrm{RV}<1.3 \mathrm{mg} / \mathrm{dL}$ ) and the estimated glomerular filtration rate (eGFR) was decreasing (eGFR $23 \mathrm{~mL} / \mathrm{min} / 1.73 \mathrm{~m}^{2}$; $\mathrm{RV}>60 \mathrm{~mL} / \mathrm{min} / 1.73 \mathrm{~m}^{2}$ ). Therefore, antivenom therapy was reinforced with 8 more vials, completing the protocol for a severe accident. On the following days, he presented
AKI (sCre $5.4 \mathrm{mg} / \mathrm{dL}$; eGFR $12.5 \mathrm{~mL} / \mathrm{min} / 1.73 \mathrm{~m}^{2}$ ), thrombocytopenia $\left(31.000 / \mathrm{mm}^{3}\right.$; RV: $\left.150.000-450.000 / \mathrm{mm}^{3}\right)$, anemia (hemoglobin $10.1 \mathrm{~g} / \mathrm{dL}$; RV: 13.5-17 g/dL), normal coagulation assays, presence of hemoglobin, protein and waxy casts in the urine, slight increase in serum indirect bilirubin levels ( $/ \mathrm{dL} ; \mathrm{RV} \leq 0.8 \mathrm{mg} / \mathrm{dL}$ ), lactate dehydrogenase elevation $(\mathrm{LDH}=3,805 \mathrm{U} / \mathrm{L}$; $\mathrm{RV}: 230-460 \mathrm{U} / \mathrm{L})$ and presence of schizocytes in peripheral blood (Figure 2). From the sixth dayof hospitalization, the patient exhibited significant improvement. Renal replacement therapy and plasmapheresis were not required, and the patient was discharged with a partial recovery of renal function on the eighth day after the snakebite (sCr $2.5 \mathrm{mg} / \mathrm{dL}$; eGFR $31.8 \mathrm{~mL} / \mathrm{min} / 1.73 \mathrm{~m}^{2}$ ). Four days after hospital discharge, days he returned to the hospital and underwent further laboratory tests that showed improvement in renal function $(\mathrm{sCr} 1.8 \mathrm{mg} / \mathrm{dL}$; eGFR $47.4 \mathrm{~mL} / \mathrm{min} / 1.73 \mathrm{~m}^{2}$ ).

\section{DISCUSSION}

The exact mechanism of TMA in snakebites remains unknown. However, it is believed that toxins in the venom may be the cause of endothelial damage ${ }^{7}$ and fibrin microthrombi deposition that result in TMA. Bothrops erythromelas venom presents no thrombin-like activity. The activity of this venom in the coagulation was attributed to a marked presence of prothrombin and activators of the factor $\mathrm{X}$ that lead to the formation of endogenous thrombin ${ }^{8,9}$. This venom contain toxins, such as serine proteinases, metalloproteinases (SVMPs), disintegrins and C-type lectin-like molecules. These venom components act on coagulation and fibrinolysis, on micro vessels and affect the platelet aggregation ${ }^{9}$. A proteomic study of B. erythromelas pointed to a predominance of SVMPs, P-III class, with Berythractivase the only P-III SVMP characterized from B. erythromelas venom ${ }^{9}$. Berythractivase, is a nonhemorrhagic metalloproteinases and a potent activator of prothrombin that is capable of increasing the incidence of systemic bleeding due to the triggering of endothelial proinflammatory and procoagulant cell responses ${ }^{3,9}$.

The thrombotic microangiopathy presented a clinical picture similar to the one of hemolytic uremic syndrome $(\mathrm{HUS})^{2}$, i.e., AKI, thrombocytopenia and microangiopathic hemolytic anemia (MAHA). Although many studies have reported the relationship between TMA and the venom-induced consumption coagulopathy (VICC), TMA in snakebite may occur without VICC ${ }^{10,11}$. VICC is characterized by prolonged clotting times caused by activation of the coagulation cascade by prothrombin, thrombin-like enzymes and factor $\mathrm{X}$ activators present in 
Table 1 - Laboratory parameters of the patient during hospital stay and after discharge.

\begin{tabular}{|c|c|c|c|c|c|c|c|c|c|c|}
\hline \multirow[b]{2}{*}{ Parameters } & \multicolumn{10}{|c|}{ Day after bite } \\
\hline & $\mathrm{D} 1$ (6h pb) & D1 (13h pb) & D2 & D3 & D4 & D5 & D6 & D7 & D8 & $\begin{array}{l}\text { D12 (after } \\
\text { discharge) }\end{array}$ \\
\hline $\begin{array}{l}\text { Hemoglobin } \\
\text { (RV:13,5-17g/dL) }\end{array}$ & 14.4 & 14 & 11.3 & 10.9 & 10.1 & 10.1 & 9.7 & 10.2 & & 11.1 \\
\hline $\begin{array}{l}\text { Hematocrit } \\
\text { (RV: } 39-50 \%)\end{array}$ & 43 & 41.9 & 34 & 32.5 & 31.1 & 29.9 & 29 & 29.6 & & 32.7 \\
\hline $\begin{array}{l}\text { Fragmented red blood cells } \\
\text { (blood film) }\end{array}$ & - & - & - & Present & Present & - & - & - & & \\
\hline $\begin{array}{l}\text { White blood cells } \\
\text { (RV:3.600- } 10.000 / \mu \mathrm{L})\end{array}$ & 15,300 & 14,030 & 14,520 & 11,750 & 10,210 & 10,470 & 12,370 & 13,800 & & 13,050 \\
\hline $\begin{array}{l}\text { Platelets }\left(\times 10^{3} / \mathrm{mm}^{3}\right) \\
\left(\mathrm{RV}: 150.000-450.000 / \mathrm{mm}^{3}\right)\end{array}$ & 229 & 194 & 74 & 34 & 31 & 55 & 131 & 191 & & 674 \\
\hline PT (RV: <14 seg) & $\mathrm{n} / \mathrm{c}^{*}$ & 15.1 & 10.9 & & 11.3 & 10.9 & 10.9 & & & \\
\hline INR (RV: <1,2) & - & 1.39 & 1 & & 1.04 & 1 & 1 & & & \\
\hline $\begin{array}{l}\text { aPTT } \\
(\mathrm{RV}:<28 \mathrm{seg})\end{array}$ & $n / c^{*}$ & 32.4 & 26.6 & & 25.6 & 26.4 & 26.6 & & & \\
\hline $\begin{array}{l}\text { Urea } \\
\text { (RV: } 13-43 \mathrm{mg} / \mathrm{dL} \text { ) }\end{array}$ & 46 & 68 & 124 & 155 & 166 & 151 & 122 & 107 & 85 & 79 \\
\hline $\begin{array}{l}\text { Creatinine } \\
\text { (RV: } 0,7-1,3 \mathrm{mg} / \mathrm{dL} \text { ) }\end{array}$ & 1.6 & 2.9 & 4.8 & 5.4 & 5.1 & 4.4 & 3.0 & 2.8 & 2.5 & 1.8 \\
\hline $\begin{array}{l}\text { Glicose } \\
\text { (RV: } 70-99 \mathrm{mg} / \mathrm{dL} \text { ) }\end{array}$ & 95 & & & & & & 153 & 73 & & \\
\hline $\begin{array}{l}\text { Sodium } \\
\text { (RV: } 135 \text { - } 148 \mathrm{mmol} / \mathrm{L})\end{array}$ & 139 & & 134 & 138 & 141 & 132 & 139 & 138 & 140 & \\
\hline $\begin{array}{l}\text { Potassium } \\
\text { (RV: } 3,5-5,3 \mathrm{mEq} / \mathrm{L} \text { ) }\end{array}$ & 4.26 & & 5.01 & 4.4 & 4.38 & 4.3 & 4.9 & 4.13 & 4.96 & 5.6 \\
\hline $\begin{array}{l}\text { CPK } \\
(\mathrm{RV}:<195 \mathrm{U} / \mathrm{L})\end{array}$ & 312 & 975 & & 2478 & 2025 & 974 & & 239 & & 151 \\
\hline $\begin{array}{l}\text { LDH } \\
\text { (RV: } 230-460 U / L)\end{array}$ & & & 1502 & 3805 & 3071 & 2016 & 1392 & 1358 & & \\
\hline $\begin{array}{l}\text { Total bilirrubin } \\
(\mathrm{RV}: \leq 1,0 \mathrm{mg} / \mathrm{dL})\end{array}$ & & & & 1.4 & 0.8 & 0.57 & 0.5 & 0.4 & & \\
\hline $\begin{array}{l}\text { Indirect bilirrubin } \\
(\mathrm{RV}: \leq 0,8 \mathrm{mg} / \mathrm{dL})\end{array}$ & & & & 1.0 & 0.5 & 0.35 & 0.3 & 0.2 & & \\
\hline $\begin{array}{l}\text { Alanineaminotransferase } \\
\text { (RV: <41U/L) }\end{array}$ & 35 & & & & & 39 & 47 & 49 & & \\
\hline $\begin{array}{l}\text { Aspartateaminotransferase } \\
\text { (RV: }<38 \mathrm{U} / \mathrm{L})\end{array}$ & 41 & & & & & 30 & 31 & 22 & & \\
\hline Hematuria & & & & +++ & + & & & & & \\
\hline Proteinuria & & & & + & Traces & & & & & \\
\hline UrinaryCasts & & & & $\begin{array}{l}\text { Granular } \\
\text { and Waxy }\end{array}$ & Hyaline & & & & & \\
\hline
\end{tabular}

$\mathrm{n} / \mathrm{c}=$ non clot $; \mathrm{pb}=$ post-bite

the venom ${ }^{2,12}$, which resolves after the toxins neutralization. There are controversies about the treatment of TMA associated with snakebite envenoming. Supportive care, antivenom administration, hemodialysis, and plasma exchange have been reported in the management of snakebite-induced $\mathrm{TMA}^{2}$. Usually, TMA associated with
VICC appears to resolve with antivenom only, once the snake venom toxins are neutralized ${ }^{11}$.

Thrombocytopenia together with microangiopathic hemolytic anemia is enough for the diagnosis of $\mathrm{TMA}^{13}$ and it is caused by snake venom toxins, such as snake venom C-type lectins (Snaclecs) ${ }^{9,14}$ being abundant in 




Figure 2 - Presence of schizocytes in peripheral blood.

B. erythromelas ${ }^{9}$. This class of protein inhibits or activates platelets by binding to receptors such as collagens or the von Willebrand factor (VWF). However, platelets activation is the most efficient way for snake venom to reduce platelets function by removing them from circulation, leading tothrombocytopenia ${ }^{14}$. The current case developed thrombocytopenia with the lowest platelets count in a delayed phase, after the second day post-bite.

Bothrops erythromelas venom presents the highest levels of factor $\mathrm{X}(\mathrm{FX})$ and prothrombin activators without showing a thrombin-like activity in comparison with other Bothrops venoms ${ }^{8}$. In the current study, the patient showed some evidence of coagulopathy (uncoagulable PT and aPTT). However, the coagulation profiles improved within 24 hours after antivenom therapy confirming VICC ${ }^{11}$.

The markers of microvascular hemolysis with anemia following snakebite envenomation are not specific ${ }^{13}$. MAHA was reported in two tiger snake envenomations that evolved with anemia, increased lactate dehydrogenase levels, increased serum indirect bilirubin levels, and fragmented red blood cells (schizocytes) in blood smears ${ }^{15}$. Similarly, this case presented with laboratory abnormalities suggesting MAHA.

The mechanistic pathway of acute kidney injury due to snakebite-associated thrombotic microangiopathy is fibrin microthrombi deposition, suggested by histological analyses reported in literature ${ }^{7,16-18}$. Our patient developed rapidly and progressive $\mathrm{AKI}$ in the first 12 hours post-bite with increasing serum creatinine levels and decreasing estimated glomerular filtration rates. Other mechanisms of AKI in snakebite are both, the direct action of venom on the kidney and inflammatory effects due to the release of various endogenous cytokines and mediators ${ }^{19}$.

Plasma exchange and renal replacement treatment (RRT) after adequate antivenom administration are the main proposed treatments for TMA following snakebites ${ }^{13,18}$. Plasmapheresis is a nonspecific treatment used in many toxicological disorders to rapidly remove toxins from the circulation. However, the effectiveness of this therapy in the treatment of snakebite-induced TMA is still uncertain ${ }^{13}$. RRT should be initiated when life-threatening changes in the fluid, electrolytes and acid-base balance are unresponsive to current medical therapy. In this study, the patient received only specific antivenom and had a favorable outcome without the the need of other therapies.

\section{CONCLUSION}

This report describes the first confirmed case of B. erythromelas bite in Northeast Brazil that evolved to TMA. The conservative treatment was effective, and there was no need for red blood cell transfusion and plasmapheresis. The severe AKI following TMA evolved with partial recovery of the renal function. The possibility of chronic kidney disease requires the follow-up of these patients and further studies.

\section{ACKNOWLEDGMENTS}

We are very grateful for the technical support provided for the development of this study. EFD and GBSJ are recipients of the grants $\mathrm{N}^{\circ} 302017 / 2018-6$ and 301174/2017-2 from the Conselho Nacional de Desenvolvimento Científico e Tecnológico (CNPq) and Coordenação de Aperfeiçoamento de Pessoal de Nível Superior (CAPES).

\section{AUTHORS' CONTRIBUTIONS}

SMBM and PLMMA performed the study, performed data collection and drafted the manuscript; GBSJ and EFD analyzed the data. All authors substantially reviewed, commented on, and approved the final manuscript.

\section{FUNDING}

No funding received for this work.

\section{REFERENCES}

1. Berling I, Isbister GK. Hematologic effects and complications of snake envenoming. Transfus Med Rev. 2015;29:82-9.

2. Bucaretchi F, Pimenta MM, Borrasca-Fernandes CF, Prado CC, Capitani EM, Hyslop S. Thrombotic microangiopathy 
following Bothrops jararaca snakebite: case report. Clin Toxicol (Phila). 2019;57:294-9.

3. Malaque CM, Duayer IF, Santoro ML. Acute kidney injury induced by thrombotic microangiopathy in two cases of Bothrops envenomation. Clin Toxicol (Phila). 2019;57:213-6.

4. Brocklebank V, Wood KM, Kavanagh D. Thrombotic microangiopathy and the kidney. Clin J Am Soc Nephrol. 2018;13:300-17.

5. Mohamed F, Endre ZH, Buckley NA. Role of biomarkers of nephrotoxic acute kidney injury in deliberate poisoning and envenomation in less developed countries. Br J Clin Pharmacol. 2015;80:3-19.

6. Endre ZH. Assessing renal recovery after acute kidney injury: can biomarkers help? Nephron. 2018;140:86-9.

7. Gn YM, Ponnusamy A, Thimma V. Snakebite induced thrombotic microangiopathy leading to renal cortical necrosis. Case Rep Nephrol. 2017;2017:1348749.

8. Nery NM, Luna KP, Fernandes CF, Zuliani JP. An overview of Bothrops erythromelas venom. Rev Soc Bras Med Trop. 2016;49:680-6.

9. Jorge RJ, Monteiro HS, Gonçalves-Machado L, Guarnieri MC, Ximenes RM, Borges-Nojosa DM, et al. Venomics and antivenomics of Bothrops erythromelas from five geographic populations within the Caatinga ecoregion of northeastern Brazil. J Proteomics. 2015;114:93-114.

10. Namal Rathnayaka RM, Ranathunga PE, Kularatne SA. Thrombotic microangiopathy, hemolytic uremic syndrome, and thrombotic thrombocytopenic purpura following humpnosed pit viper (Genus: Hypnale) envenoming in Sri Lanka. Wilderness Environ Med. 2019;30:66-78.
11. Isbister GK. Snakebite doesn't cause disseminated intravascular coagulation: coagulopathy and thrombotic microangiopathy in snake envenoming. Semin Thromb Hemost. 2010;36:444-51.

12. Kamiguti AS, Cardoso JL, Theakston RD, Sano-Martins IS, Hutton RA, Rugman FP, et al. Coagulopathy and haemorrhage in human victims of Bothrops jararaca envenoming in Brazil. Toxicon. 1991;29:961-72.

13. Noutsos T, Currie BJ, Isbister GK. Snakebite associated thrombotic microangiopathy: a protocol for the systematic review of clinical features, outcomes, and role of interventions. Syst Rev. 2019;8:212.

14. Clemetson KJ. Snaclecs (snake C-type lectins) that inhibit or activate platelets by binding to receptors. Toxicon. 2010;56:1236-46.

15. Casamento AJ, Isbister GK. Thrombotic microangiopathy in two tiger snake envenomations. Anaesth Intensive Care. 2011;39:1124-7.

16. Mitrakrishnan JY, Bandula CW, Mitrakrishnan CS, Somaratna $\mathrm{K}$, Jeyalakshmy S. Haemolytic uremic syndrome a hitherto unreported complication of humpnosed viper envenomation. Indian J Hematol Blood Transfus. 2013;29:116-8.

17. Chugh KS. Snake-bite-induced acute renal failure in India. Kidney Int. 1989;35:891-907.

18. Mohan G, Guduri PR, Shastry S, Kandasamy D. Thrombotic microangiopathy in hematotoxic snakebites and its impact on the prognosis: an entity often overlooked. J Thromb Thrombolysis. 2019;48:475-82.

19. Sitprija V. Snakebite nephropathy. Nephrology (Carlton). 2006;11:442-8. 